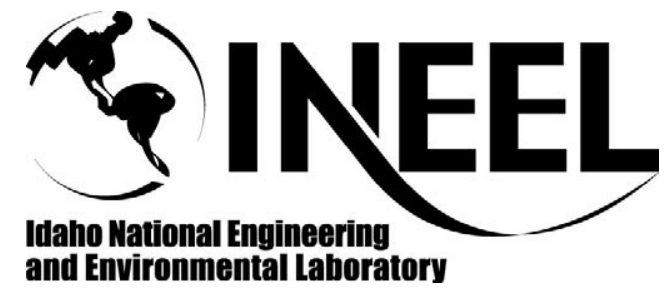

Ilaho National Engineering

and Environmental Laboratory
INEEL/CON-02-00096
PREPRINT

Trace Elements And Common Ions In Southeastern Idaho Snow: Regional Air Pollutant Tracers For Source Area Emissions

September 10, 2002

Air Quality III - Mercury, Trace Elements, And Particulate Matter

This is a preprint of a paper intended for publication in a journal or proceedings. Since changes may be made before publication, this preprint should not be cited or reproduced without permission of the author.

This document was prepared as a account of work sponsored by an agency of the United States Government. Neither the United States Government nor any agency thereof, or any of their employees, makes any warranty, expressed or implied, or assumes any legal liability or responsibility for any third party's use, or the results of such use, of any information, apparatus, product or process disclosed in this report, or represents that its use by such third party would not infringe privately owned rights. The views expressed in this paper are not necessarily those of the U.S. Government or the sponsoring agency. 


\title{
TRACE ELEMENTS AND COMMON IONS IN SOUTHEASTERN IDAHO SNOW: REGIONAL AIR POLLUTANT TRACERS FOR SOURCE AREA EMISSIONS
}

\author{
Mike Abbott* and Jeff Einerson \\ Idaho National Engineering and Environmental Laboratory \\ PO Box 1625 \\ Idaho Falls, ID 83415-2107 \\ Paul Schuster \\ U.S. Geological Survey - National Research Program \\ 3215 Marine St. Suite E127 \\ Boulder, CO 80303 \\ David Susong \\ U.S. Geological Survey - Water Resources Divsion \\ 2329 West Orton Circle \\ West Valley City, UT 84119
}

\begin{abstract}
Snow samples were collected in southeastern Idaho over two winters to assess trace elements and common ions concentrations in air pollutant fallout across the region. The objectives were to: 1) develop sampling and analysis techniques that would produce accurate measurements of a broad suite of elements and ions in snow, 2) identify the major elements in regional fallout and their spatial and temporal trends, 3) determine if there are unique combinations of elements that are characteristic to the major source areas in the region (source profiles), and 4) use pattern recognition and multivariate statistical techniques (principal component analysis and classical least squares regression) to investigate source apportionment of the fallout to the major source areas. In the winter of 2000-2001, 250 snow samples were collected across the region over a 4-month period and analyzed in triplicate using inductively-coupled plasma mass spectrometry (ICP-MS) and ion chromatography (IC). Thirty-nine (39) trace elements and 9 common ions were positively identified in most samples. The data were analyzed using pattern recognition tools in the software, Pirouette $\mathbb{R}$ (Infometrix, Inc.). These results showed a large crustal component (Al, Zn, Mn, Ba, and rare earth elements), an overwhelming contribution from phosphate processing facilities located outside Pocatello in the southern portion of the ESRP, some changes in concentrations over time, and no obvious source area profiles (unique chemical signatures) other than at Pocatello. Concentrations near a major U.S. Department of Energy industrial complex on the Idaho National Engineering and Environmental Laboratory (INEEL) were lower than those observed at major downwind communities. In the winter of 2001-2002, we tried a new sampling design (and collected 135 additional samples) in an attempt to estimate pure emission profiles from the major source areas in the region and used classical least squares regression (CLS) to source apportion these profiles at four downwind mixing sites.
\end{abstract}




\section{INTRODUCTION}

The atmosphere and the earth's surface are currently the primary environmental transport pathways for pollutants emitted from most U.S. Department of Energy (DOE) waste treatment facilities. Yet, our scientific understanding of the airborne transport and surface deposition (fallout) of these contaminants on a regional scale is limited. Understanding the relative contribution of regional sources is critical for evaluating emissions control strategies, selecting waste treatment options, and for public understanding. Current assessment techniques use relatively simple air dispersion models or only measure a few generic pollutants (e.g., PM-10, NOx, SOx). Because of the physical/chemical complexities of the atmosphere and the wide array of source inputs (most of which have not been adequately characterized), no transport model can reliably predict source contributions of ubiquitous air pollutants at far-field $(>50 \mathrm{~km})$ downwind locations.

As an alternative, various types of multivariate "receptor" models have been developed", which use relationships of contaminant concentrations at the point of impact to better understand source inputs rather than source-oriented dispersion models. Most of the work done has been to source apportion specific sources (coal-fired power plant) or source types (oil combustion, crustal) ${ }^{2}$ using particle concentrations in air. Few efforts have been made to identify characteristic source "area" signatures, which may be a mixture of many different source types, that can be traced and quantified at regional scales ${ }^{3,4}$. It is not at all clear that composite signatures from specific source areas can be identified or that they will be unique enough to be useful.

We measured trace element and common ion concentrations in snow across the Eastern Snake River Plain (ESRP) in southeastern Idaho over two winters (2000-2001 and 20012002). Snow was used as a sampling medium because it is an efficient scavenger of air pollutants, usually remains on the ground for sampling after the event, and is relatively simple and inexpensive to collect ${ }^{5}$. We were interested in measuring deposition because of its potential for long-term buildup and transport into the food-chain and because air pollutants may deposit at different rates. Our objectives were to: 1) identify and quantify the major constituents in fallout across the ESRP, 2) use pattern recognition and multivariate statistical techniques (principal component analysis) to determine if there are unique combinations of elements/ions that may be attributable to major source areas in the region (source area profiles or signatures), and 3) investigate source apportionment of these source area profiles at downwind locations where source area emissions might mix.

\section{EXPERIMENTAL}

In the winter of 2000-2001, a total of 250 snow samples were collected at the following locations (Figure 1): 1) nine regional background sites surrounding the ESRP (once/monthJanuary through March), 2) west slope of the Teton Range (March), and 3) a 5-km radius, 64-site grid surrounding the Idaho Nuclear Technology and Engineering Center (INTEC), a major industrial complex located on the Idaho National Engineering and Environmental Laboratory (INEEL). Clean sampling methods ${ }^{6}$ were used that included the use of acid-clean 
250-mL LDPE and HDPE bottles for trace elements and common ion analysis, 500-mL double-bagged teflon bottles for $\mathrm{Hg}$ analysis, and shoulder-length, powder-free gloves. All samples were maintained in a frozen state through shipment to the laboratory. Trace element and common ion samples were sent to the U.S. Geological Survey National Research Program laboratory in Boulder, $\mathrm{CO}$, where they were analyzed in triplicate using inductivelycoupled plasma mass spectrometry (ICP-MS - Perkin-Elmer Sciex Elan 6000) ${ }^{7}$ and ion chromatography (IC). Prior to ICP-MS, the samples were melted, filtered (5- $\mu \mathrm{m}$ sterile syringe), and acidified to $\mathrm{pH}<2$ using double-distilled $\mathrm{HNO}_{3}$. Mercury samples were analyzed by the U.S. Geological Survey's Wisconsin District Mercury Research Laboratory in Madison using approved EPA methods ${ }^{8}$. Laboratory QA/QC procedures included the analysis of blanks (field processing, trip, sample processing, and instrument), internal standards, and NIST Standard Reference Material.

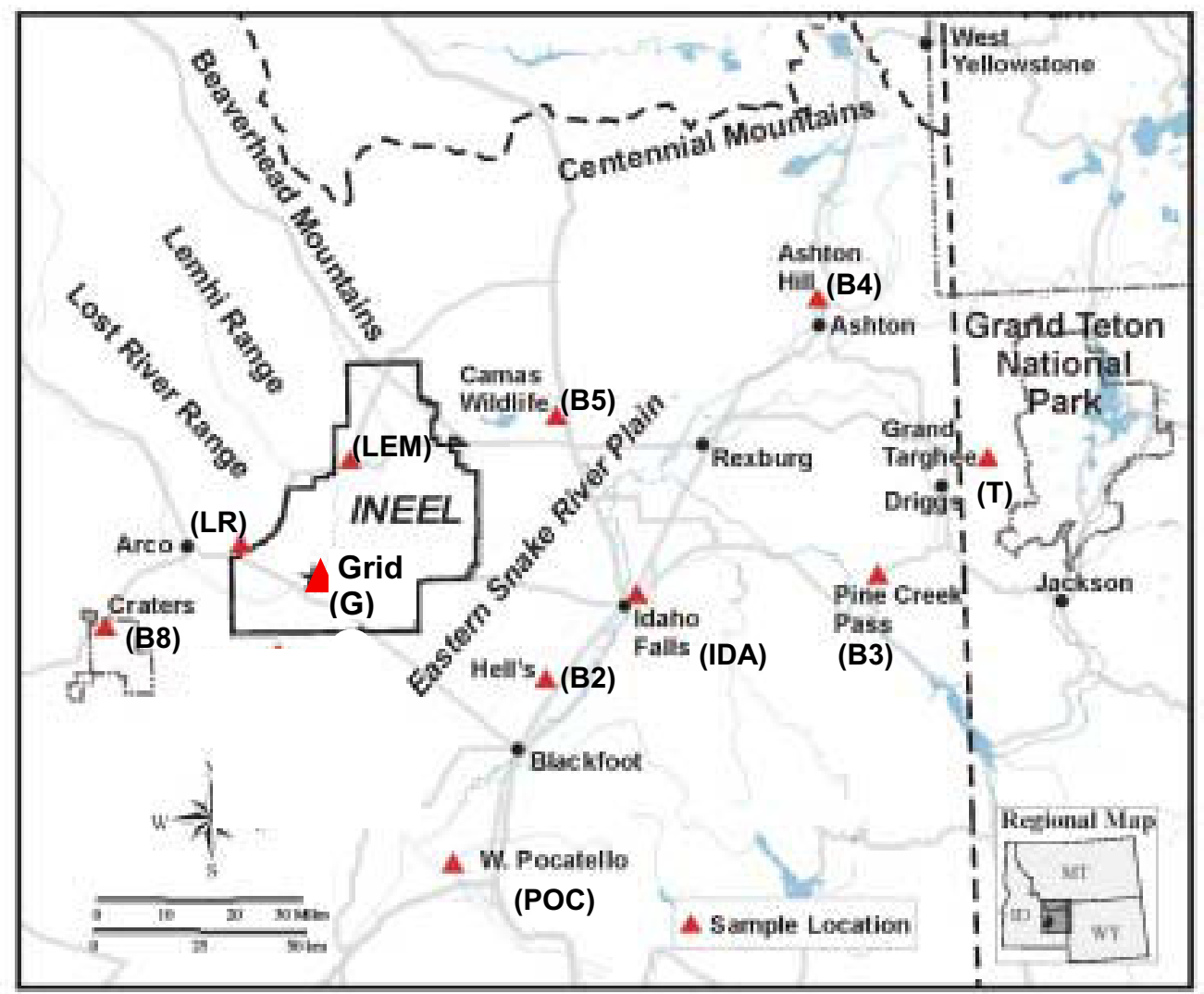

Figure 1. Study area showing sampling locations in the winter of 2000-01.

The sampling methods were modified in 2002 based on the results from the previous year's sampling. This included: 1) sample filtration to $0.8 \mu \mathrm{m}$, to reduce the crustal component, 2) three replicate samples at each site to better understand sample variability, 3) upwind and downwind sampling around the major source areas to characterize their net trace element input (source profile sampling), and 4) sampling downwind in an area where two or more source areas might mix (mixing zone sampling). These latter two steps were done to investigate classical least-squares regression (CLS) as a tool for source apportionment of fallout in downwind mixing zones. 
To identify optimum sampling locations for the source profile and mixing site sampling, we used the INELVIZ plume prediction display system after each snowfall event to plot air masses downwind of source areas. INELVIZ uses the National Oceanic and Atmospheric Administration (NOAA) MDIFF ${ }^{9}$ trajectory model and wind field telemetry data from a 35station Mesonet network on the ESRP to predict plume trajectories around a user-selected source.

A total of 135 additional samples were collected from January-March 2002 after three major snowfall events (Figures 2-3) with the objectives of: 1) source profile sampling around the five major source areas on the ESRP-- Rexburg (RXB), Idaho Falls (IDA), Blackfoot (BLA), Pocatello (POC), and at a site next to Interstate-15 (HEL) for assessment of vehicular emissions (January 28-29), 2) multiple source mixing zone sampling downwind from RXB and IDA (February 20), and 3) source profile sampling around INTEC [CPP] on the INEEL on March 7. Source profile sampling was done at one upwind location and two downwind locations, one at the edge of the source area (town limits) and one approximately $5-\mathrm{km}$ downwind. The mixing zone sampling on February 20 was done at four locations, one site approximately $35-\mathrm{km}$ east-northeast of IDA and three sites ranging from $25-45 \mathrm{~km}$ northeast of RXB. INELVIS modeling showed that these sites may have been impacted by emissions from RXB, IDA, and BLA during the snowfall event (Figure 3). Three replicate samples were taken at each location at either 1-m or 10-m spacing between replicates.

\section{Data Analysis}

In the 2000-01 data set, elements were evaluated if at least $10 \%$ of the samples were greater than detection limit ( 34 out of 40 analytes). For the 2002 data, this criteria was increased to $45 \%$ detection ( 27 out of 44 analytes). For those elements retained for analysis, individual sample concentrations less than the minimum detection limit (MDL) were set to $50 \%$ of the detection limit. Some small blank corrections were done for a few of the elements in the first year's data. 


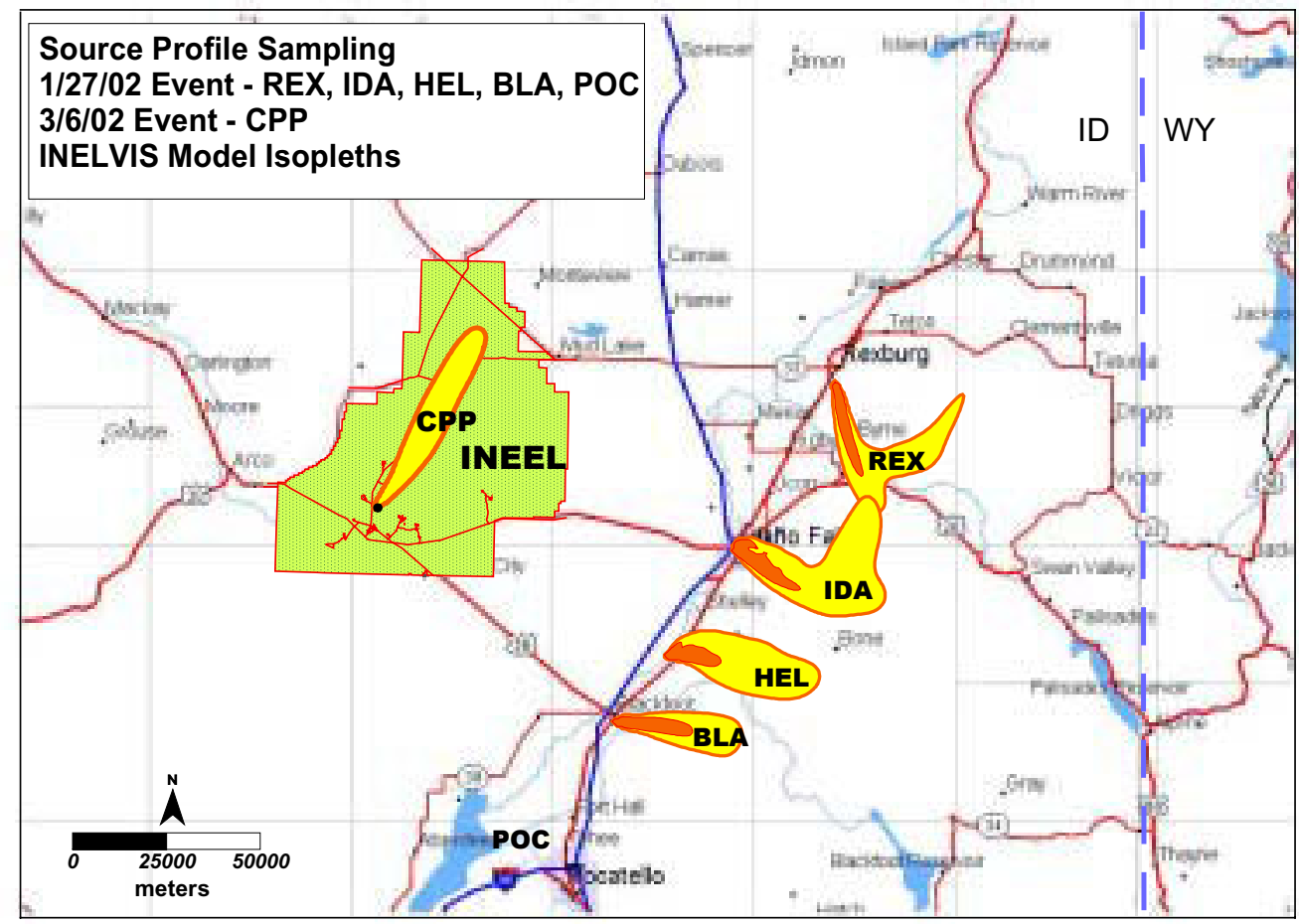

Figure 2. Upwind/downwind sampling locations around major source areas were determined using INELVIZ modeling of air masses during a 1/27/02 snowfall event.

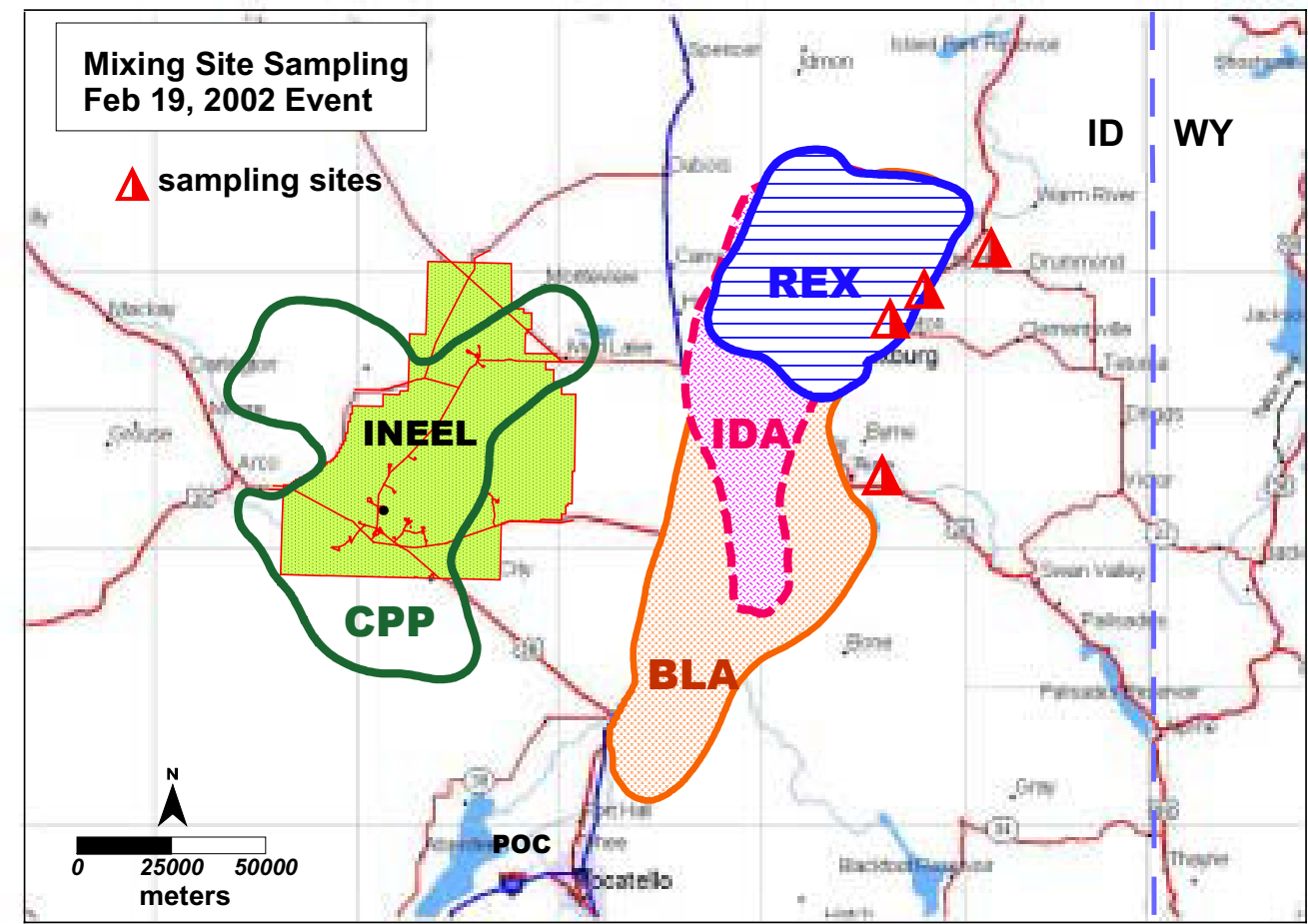

Figure 3. Mixing zone sampling locations (where emissions from 2 or more sources might mix) were determined using INELVIZ modeling of air masses during a 2/19/02 snowfall event. 
The data were evaluated using various types of pattern-recognition tools in the software, Pirouette ${ }^{\circledR}{ }^{1}$. These tools use graphical and multivariate statistical techniques that can identify correlated variables (element or ion concentrations) that may be unique for a particular source type. One of these methods is principal component analysis (PCA) which calculates linear combinations of the multivariate data set that best describe sample variability. When applied to environmental concentrations, these PC factors describe unique combination of elements that characterize the source(s) impacting the site (source signatures). Samples with high scores on one or more of these factors indicate that the samples are impacted by the same source(s). The elements that define these source signatures are given by the principal component "loadings." PCA was conducted for the 2000/01 data to see if clustering occurred by sampling site which would indicate unique chemical signatures at the sites.

\section{Source Apportionment using CLS}

Using the 2001-02 data set, a new method for source apportionment of major source areas was developed. This method assumes that inputs to the system from the major source areas could be quantified using the difference between the downwind and upwind source profile concentrations, and that all other inputs ("background") could be quantified using the upwind concentrations measured around each source area. A classical least-squares (CLS) regression model in Pirouette was built based on these inputs, and the model was used to predict fractional contributions from the source areas at the four mixing zone sites sampled on 2/20. CLS regression is a statistical technique that establishes a functional relationship between some quantitative sample property, the dependent variable, and one or more independent variables. In the case of more than one dependent variable, this becomes multivariate CLS. The functional relationship developed here is the prediction of the fractional contribution of source inputs at the mixing site, the dependent variables, based on the measured concentrations at the mixing sites, the independent variables.

The source inputs used to build ("run") our CLS model were the background (S1) inputs (upwind concentrations) at BLA, IDA, RXB, POC, and CPP (BLAS1, IDAS1, RXBS1, POCS1, CPPS1) and the source profile (S2) inputs from each of these areas (BLAS2, IDAS2, RXBS2, POCS2, CPPS2, HELS2). In this model building step, the independent variables are element/ion concentrations at each sampling site, and the dependent variables are the fractional contributions of the measured constituents at each source profile sampling location (assumed to be 1 in the model building step).

After building the model using the assumed "pure" source profile inputs described above, the model was used to predict fractional source contributions at the mixing sites. In this prediction, the independent variables are the element/ion concentrations at the mixing sites, and the dependent variables (predicted output) are the fractional contribution of each source area and background source at the mixing site. These fractional contributions were then multiplied by the total measured concentration at the mixing site to obtain the source-specific concentrations. The predicted source-specific concentrations were then summed and the results were compared to the measured concentrations at the mixing site to produce a

${ }^{1}$ Infometrix, Inc., (http://www.infometrix.com) 
predicted-to-measured ratio (predicted-to-observed ratio in the modeling world). This ratio was used to measure how well the CLS model performed.

\section{RESULTS AND DISCUSSION}

\section{0-01 Data Set}

The average concentrations for the 35 trace elements and 9 common ions identified in at least $10 \%$ of the 2000-2001 samples are shown in Figure 4. Concentrations were much greater at the Idaho Falls and Pocatello sites compared to those at the INEEL and at the Craters site (Figure 4) for nearly all constituents. Craters is located in a relatively pristine area (Craters of the Moon National Monument) on the upwind side of the ESRP and is only impacted by natural sources (Figure 1). Average INEEL concentrations are nearly identical to those at the Craters site except for $\mathrm{Ni}$, which is 15 times higher at the INEEL. This higher $\mathrm{Ni}$

concentration may be due to the significant oil combustion sources located there. Significant elements in the Pocatello samples included: V, Cd, Fl', U, Mo, and Tl. These measurements provided a good baseline for understanding the types, quantities, and spatial variability of air pollutant fallout in the region.

PCA performed on the 2000-01 data set did not reveal significant clustering by source area except for the Pocatello sites (Figure 5) which had high PC 1 and 2 scores. The data also showed a shift (reduction) in the PC 1 scores for the samples taken on 2/21/02 compared to those taken on the other dates indicating that the relative concentrations have changed over time. This shift could be due to changes in local source emissions and/or different air mass histories (and background source inputs) in the snowpack between the two sampling dates.

The chemical loadings for PC 1 consisted of a large number of elements - most of the rare earth elements (REEs) and Al. This REE component is probably due to a combination of fugitive emissions from the phosphorus industry in POC and crustal (blowing dust) input. The chemical loadings for PC 2 were Tl, Cd, Zn, V, and Ni. This component is probably due to a combination of emissions from phosphate ore processing and oil combustion at POC (V/Ni). PC 3 was loaded with Mo, Be, Sb, and Tl. 

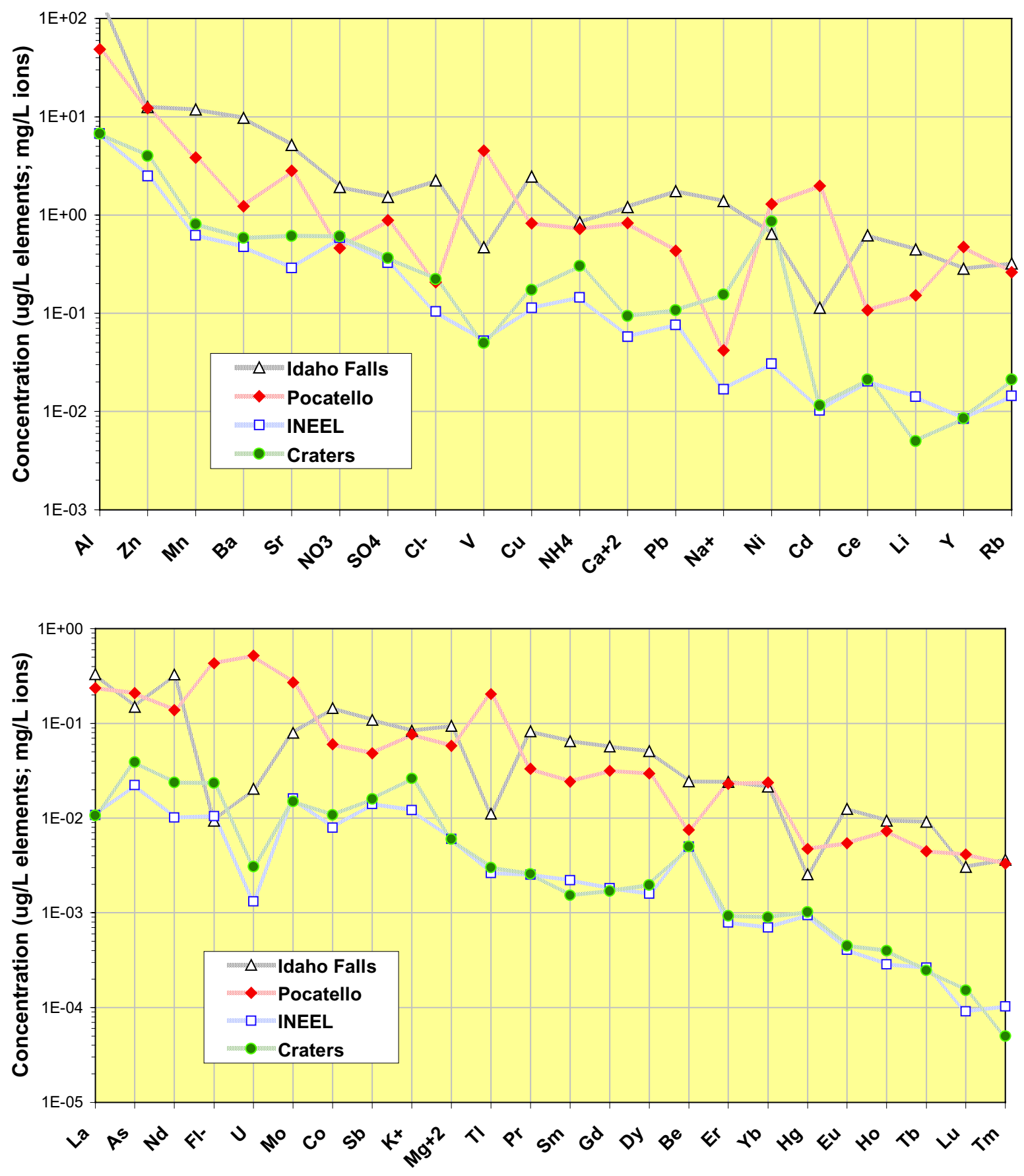

Figure 4. Trace element and ion concentrations in snow near Idaho Falls, Pocatello, the INEEL, and Craters of the Moon National Monument measured in the winter of 2000-01. 


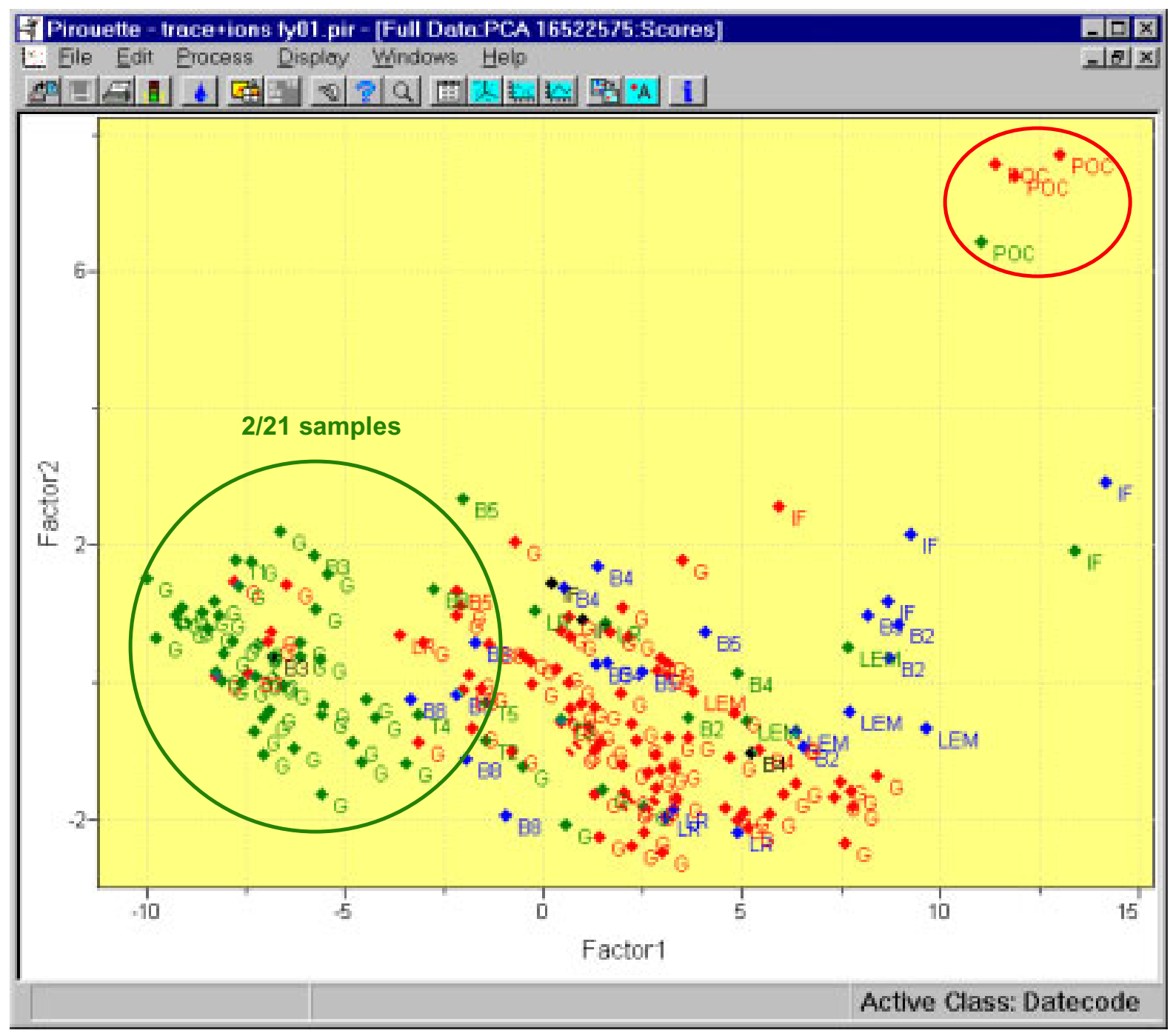

Figure 5. PC 1 and 2 scores for the 2000-01 data set (see Figure 1 for sample site names; $\mathrm{G}=$ INEEL grid sites).

\section{1-02 Data Set}

Laboratory analyses of the 2001-02 samples identified 27 trace elements and 6 common ions that were detected in at least $45 \%$ of the samples. The results showed maximum downwind concentrations at POC to be 1-3 orders of magnitude higher than those observed at any of the other source area for all constituents except $\mathrm{NO}_{3}{ }^{-}$(Figure 6). 

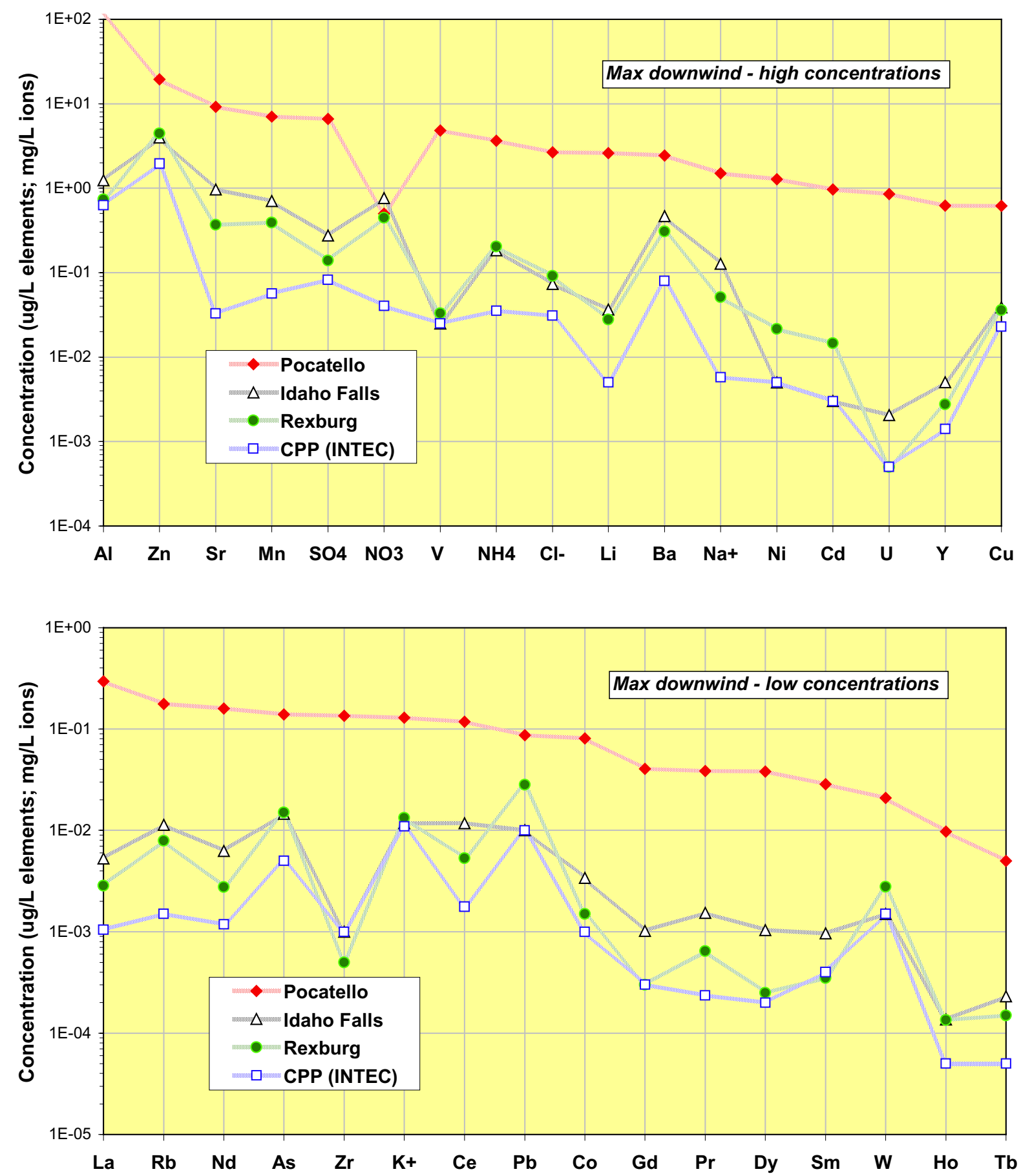

Figure 6. Maximum trace element and ion concentrations in snow downwind of major emission source areas in the ESRP measured in the winter of 2001-02. 
These higher POC concentrations probably better reflect that source area's input compared to the 2000-01 samples because of the use of INELVIS to identify sampling locations in the maximum downwind impact zone. The upwind (background) concentrations at POC (not shown) were similar to those at the other source areas. Concentrations at IDA, RXB and $\mathrm{CPP}$ were similar with the exception of several elements at $\mathrm{CPP}\left(\mathrm{Sr}, \mathrm{Mn}, \mathrm{NO}^{-}, \mathrm{NH} 4, \mathrm{Li}\right.$, $\mathrm{Na}^{+}, \mathrm{Cd}, \mathrm{Rb}, \mathrm{Nd}, \mathrm{As}, \mathrm{Ce}, \mathrm{Pr}, \mathrm{Ho}$, and $\mathrm{Tb}$ ) which were lower. Concentrations of $\mathrm{Ni}, \mathrm{Cd}$, and $\mathrm{Pb}$ were somewhat higher at RXB than IDA, and IDA had higher concentrations than RXB for some of the rare earths probably due to higher crustal (blowing dust) input at the IDA downwind sampling location.

The elements/ions with greater downwind concentrations than upwind (background) concentrations are listed in Table 1 for each of the source areas. These elements are assumed to be emitted from sources in that area. Positive differences that may have been due to random or sampling error (rather than actual source area emissions) were not considered to be important because their relative effects in the CLS modeling would be small.

Table 1. Element/ion inputs from source areas.

\begin{tabular}{|l|l|}
\hline Source Area & Constituent released (downwind>upwind) \\
\hline POC & all, except $\mathrm{NO}_{3}$ \\
\hline IDA & $\mathrm{NO}_{3}, \mathrm{SO}_{4}, \mathrm{Cl}^{-}, \mathrm{Na}^{+}, \mathrm{K}^{+}, \mathrm{Al}, \mathrm{Sr}, \mathrm{Mn}, \mathrm{Ba}, \mathrm{Li}, \mathrm{Rb}, \mathrm{Co}, \mathrm{U}, \mathrm{Y}, \mathrm{REEs}$ \\
\hline CPP & $\mathrm{SO}^{4}, \mathrm{Cl}^{-}, \mathrm{K}^{+}, \mathrm{Zn}, \mathrm{Al}, \mathrm{Ba}, \mathrm{Cu}, \mathrm{Ni}, \mathrm{Pb}, \mathrm{Y}, \mathrm{Ce}, \mathrm{Nd}, \mathrm{La}$ \\
\hline HEL & $\mathrm{Cl}^{-}, \mathrm{Na}^{+}, \mathrm{Li}, \mathrm{Ni}, \mathrm{Co}, \mathrm{W}, \mathrm{Sm}, \mathrm{Tb}$ \\
\hline RXB & $\mathrm{SO} 4, \mathrm{Cl}^{-}, \mathrm{Na}^{+}, \mathrm{K}^{+}, \mathrm{Zn}, \mathrm{Cu}, \mathrm{Li}, \mathrm{Cd}, \mathrm{Zr}, \mathrm{Tb}, \mathrm{V}$ \\
\hline BLA & $\mathrm{Ba}, \mathrm{W}$ \\
\hline
\end{tabular}

\section{Source Apportionment using CLS}

The results from the CLS modeling showed that 3 sources were responsible for the majority of the constituents deposited at the four mixing sites--BLAS1 (background), RXBS2 (source area), and CPPS1 (background) (Table 2). The RXB source contribution was from 15-27\% of the total measured fallout with the remaining being due to other background (S1) sources. It is important to recognize that the background concentrations for each site are not really unique for that source. Rather, they are a measure of everything else except that source and could be similar (or different) than the background concentrations at other source areas. The main finding from these test cases is that, of the source areas evaluated, only RXB (Rexburg) contributed fallout at the mixing sites evaluated. It is just as important to note that sources at IDA, BLA, HEL, or CPP did not contribute to fallout at these mixing sites. These results are reasonable based on wind patterns observed during the snowfall event (Figure 3). 
Table 2. CLS model predictions of source contributions at the mixing sites.

\begin{tabular}{|c|c|c|c|c|}
\hline & \multicolumn{4}{|c|}{ Percent (\%) contribution at mixing site: } \\
\hline Source $^{\mathbf{a}}$ & RXBM1 & RXBM2 & RXBM3 & IDAM1 \\
\hline HELS2 & 0 & 0 & 0 & 0 \\
\hline BLAS1 & 44 & 39 & 39 & 45 \\
\hline BLAS2 & 2 & 1 & 0 & 1 \\
\hline IDAS1 & 0 & 0 & 0 & 0 \\
\hline IDAS2 & 0 & 0 & 0 & 0 \\
\hline RXBS1 & 0 & 0 & 0 & 0 \\
\hline RXBS2 & 15 & 23 & 27 & 19 \\
\hline POCS1 & 0 & 1 & 3 & 0 \\
\hline POCS2 & 0 & 0 & 0 & 0 \\
\hline CPPS1 & 38 & 36 & 31 & 35 \\
\hline CPPS2 & 0 & 0 & 0 & 0 \\
\hline
\end{tabular}

${ }^{\mathrm{a}} \mathrm{S} 1$ = background (upwind of source area); S2 = source area (downwind-upwind).

To determine how well the model performed, we multiplied the predicted source proportions (Table 2) by the concentrations measured for each contributing source (the source profile sampling results) and summed the products. These values were then divided by the measured concentrations at the mixing sites to obtain a predicted-to-measured $(\mathrm{P} / \mathrm{M})$ ratio for each constituent. This ratio indicates the fraction of all contributing sources that were accounted for in the prediction. A perfect prediction would give a $\mathrm{P} / \mathrm{M}$ ratio of one while a ratio less than one suggests that there are sources contributing to the mixing site that have not been accounted for. A ratio significantly greater than one indicates a problem with the prediction for the specific constituent and mixing site, since the source inputs cannot exceed what was measured at the mixing site. Table 3 presents the $\mathrm{P} / \mathrm{M}$ ratios for two of the four mixing sites, RXBM1 and IDAM1. A P/M ratios for all four mixing sites are summarized in Table 4. 
Table 3. Comparison of the predicted to measured concentrations for RXBM1 and IDAM1.

\begin{tabular}{|c|c|c|c|c|c|c|c|}
\hline \multicolumn{4}{|c|}{ RXBM1 } & \multicolumn{4}{|c|}{ IDAM1 } \\
\hline & $\begin{array}{c}\text { Predicted } \\
\text { Conc. }\end{array}$ & $\begin{array}{c}\text { Measured } \\
\text { Conc. }\end{array}$ & Ratio & & $\begin{array}{c}\text { Predicted } \\
\text { Conc. }\end{array}$ & $\begin{array}{c}\text { Measured } \\
\text { Conc. }\end{array}$ & Ratio \\
\hline $\mathrm{Cl}^{-}$ & 0.04612 & 0.11380 & 0.41 & $\mathrm{Cl}^{-}$ & 0.04906 & 0.25597 & 0.19 \\
\hline $\mathrm{SO}_{2}^{4}$ & 0.08520 & 0.44380 & 0.19 & $\mathrm{SO}_{2}^{4}$ & 0.08866 & 0.61382 & 0.14 \\
\hline $\mathrm{Na}$ & 0.03024 & 0.02735 & 1.11 & $\mathrm{Na}$ & 0.03235 & 0.03170 & 1.02 \\
\hline $\mathrm{NH}_{\mathrm{r}}$ & 0.19629 & 0.95328 & 0.21 & $\mathrm{NH}_{\mathrm{r}}$ & 0.20022 & 1.24308 & 0.16 \\
\hline $\mathbf{K}$ & 0.01733 & 0.02033 & 0.85 & $\mathrm{~K}$ & 0.01779 & 0.03363 & 0.53 \\
\hline $\mathrm{Al}$ & 1.42115 & 1.76535 & 0.81 & $\mathrm{Al}$ & 1.44702 & 2.54232 & 0.57 \\
\hline $\mathrm{Ba}$ & 0.20740 & 0.98546 & 0.21 & $\mathrm{Ba}$ & 0.20936 & 0.73388 & 0.29 \\
\hline $\mathrm{Cu}$ & 0.32222 & 0.16075 & 0.20 & $\mathrm{Cu}$ & 0.03291 & 0.20928 & 0.16 \\
\hline La & 0.00490 & 0.00553 & 0.88 & $\mathrm{La}$ & 0.00500 & 0.00832 & 0.60 \\
\hline $\mathrm{Zn}$ & 1.52765 & 3.41555 & 0.45 & $\mathrm{Zn}$ & 1.59877 & 2.86405 & 0.56 \\
\hline $\mathrm{Ce}$ & 0.00880 & 0.01090 & 0.81 & $\mathrm{Ce}$ & 0.00898 & 0.01508 & 0.60 \\
\hline$Y$ & 0.00549 & 0.00594 & 0.92 & $\mathrm{Y}$ & 0.00557 & 0.00743 & 0.75 \\
\hline $\mathrm{Mn}$ & 0.28474 & 0.65036 & 0.44 & $\mathrm{Mn}$ & 0.28982 & 0.83232 & 0.35 \\
\hline $\mathrm{Sr}$ & 0.33838 & 0.31797 & 1.06 & $\mathrm{Sr}$ & 0.34775 & 0.51733 & 0.67 \\
\hline Pr & 0.00122 & 0.00141 & 0.86 & $\operatorname{Pr}$ & 0.00124 & 0.00184 & 0.68 \\
\hline $\mathrm{Nd}$ & 0.00493 & 0.00629 & 0.78 & $\mathrm{Nd}$ & 0.00503 & 0.00776 & 0.65 \\
\hline $\mathrm{Rb}$ & 0.01155 & 0.02291 & 0.50 & $\mathrm{Rb}$ & 0.01176 & 0.03247 & 0.36 \\
\hline $\mathrm{Ni}$ & 0.00701 & 0.03354 & 0.21 & $\mathrm{Ni}$ & 0.00697 & 0.02445 & 0.29 \\
\hline $\mathrm{Tb}$ & 0.00015 & 0.00019 & 0.81 & $\mathrm{~Tb}$ & 0.00015 & 0.00034 & 0.46 \\
\hline $\mathrm{Li}$ & 0.01435 & 0.05108 & 0.28 & $\mathrm{Li}$ & 0.01473 & 0.04847 & 0.30 \\
\hline $\mathrm{Co}$ & 0.00232 & 0.00525 & 0.44 & $\mathrm{Co}$ & 0.00233 & 0.00657 & 0.35 \\
\hline Dy & 0.00087 & 0.00094 & 0.93 & Dy & 0.00087 & 0.00117 & 0.74 \\
\hline $\mathrm{Gd}$ & 0.00091 & 0.00125 & 0.72 & $\mathrm{Gd}$ & 0.00092 & 0.00158 & 0.58 \\
\hline Ho & 0.00021 & 0.00023 & 0.92 & Ho & 0.00022 & 0.00023 & 0.95 \\
\hline $\mathrm{W}$ & 0.00197 & 0.00150 & 1.31 & $\mathrm{~W}$ & 0.00194 & 0.00430 & 0.45 \\
\hline $\mathrm{Sm}$ & 0.00068 & 0.00099 & 0.69 & $\mathrm{Sm}$ & 0.00068 & 0.00122 & 0.56 \\
\hline $\mathrm{Zr}$ & 0.00299 & 0.00439 & 0.68 & $\mathbf{Z r}$ & 0.00282 & 0.00311 & 0.90 \\
\hline $\mathrm{Cd}$ & 0.00306 & 0.03021 & 0.10 & $\mathrm{Cd}$ & 0.00322 & 0.03161 & 0.10 \\
\hline $\mathrm{U}$ & 0.00089 & 0.00165 & 0.54 & $\mathrm{U}$ & 0.00089 & 0.00252 & 0.36 \\
\hline As & 0.00410 & 0.09855 & 0.04 & As & 0.00400 & 0.10222 & 0.04 \\
\hline $\mathrm{V}$ & 0.01524 & 0.07824 & 0.19 & $\mathrm{~V}$ & 0.01495 & 0.08613 & 0.17 \\
\hline Average $^{\mathrm{a}}$ & & & 0.58 & Average & & & 0.47 \\
\hline
\end{tabular}

${ }^{a}$ Average of the values less than or equal to 1.0

Table 4. Summary of predicted source-specific constituent concentrations.

\begin{tabular}{|c|c|c|c|}
\hline Site & Good Prediction & Average $\mathbf{P} / \mathbf{M}^{\mathbf{b}}$ & $\begin{array}{c}\text { No. of constituents with } \\
\mathbf{P} / \mathbf{M}>\mathbf{1}^{\mathbf{c}}\end{array}$ \\
\hline RXBM1 & 8 of 31 constituents & 0.58 & 1 \\
\hline RXBM2 & 8 of 31 constituents & 0.55 & 3 \\
\hline RXBM3 & 1 of 31 constituents & 0.36 & 14 \\
\hline IDAM1 & 3 of 31 constituents & 0.47 & 0 \\
\hline
\end{tabular}

"A "good" prediction is assumed to occur when the $\mathrm{P} / \mathrm{M}$ ratio is $0.85-1.15( \pm 15 \%$ of 1$)$.

${ }^{\mathrm{b}}$ Average of the valid predictions, those having $\mathrm{P} / \mathrm{M}$ ratios less than or equal to 1.15.

${ }^{\mathrm{c}}$ Assumed to be an invalid prediction. 
When the $\mathrm{P} / \mathrm{M}$ ratio is averaged over all constituents (Table 4), the CLS model predicts from $36-58 \%$ of the total measured fallout. The constituents fully accounted for in the source apportionment (have $\mathrm{P} / \mathrm{M}$ ratios of approximately 1 ) are:

\author{
RXBM1 -- $\mathrm{Na}^{+}, \mathrm{K}^{+}, \mathrm{La}, \mathrm{Y}, \mathrm{Sr}, \mathrm{Pr}, \mathrm{Dy}$, and Ho. \\ RXBM2 -- $\mathrm{Na}^{+}, \mathrm{La}, \mathrm{Ce}, \mathrm{Sr}, \mathrm{Nd}, \mathrm{Tb}, \mathrm{Dy}$, and $\mathrm{Zr}$ \\ RXBM3 -- Mn \\ IDAM1 $-\mathrm{Na}^{+}$, Ho, $\mathrm{Zr}$
}

\title{
CONCLUSIONS
}

This 2-year snow sampling effort produced the first high-resolution regional measurements of trace elements and common ions in air pollutant fallout across the ESRP. More than 35 trace elements and 9 ions were quantified. The highest concentrations observed in the region for most constituents occurred at Pocatello sites (factors of 10-1000 higher), likely due to the large phosphorus industry located there, and the lowest concentrations were found near the INTEC (CPP) facility.

Principal component analysis was performed on the first year's data. Clustering by sampling location, indicating a unique area-specific chemical signature, was only observed for the Pocatello sites, which were characterized by a large number of rare earth elements and Al. Clustering at the other regional sites was not apparent likely due to relatively low emission source strengths in these areas, relatively high crustal input (mostly rare earth elements) across the region, and apparent changes in source profiles (source emissions and crustal input) over time.

In 2002, we investigated a new method to assess the relative impacts of source areas in the region that used: 1) air dispersion modeling of air masses during snowfall events to identify optimum sampling locations, 2) upwind/downwind sampling around the source areas immediately after snowfall events to quantify their net inputs and the background inputs, and 3) CLS modeling of these inputs to source-apportion fallout at downwind areas (mixing zones) where plumes from several source areas might mix. The CLS modeling showed reasonable results $-15-27 \%$ of the fallout was from a source area $(\mathrm{RXB})$ that, based on plume projections, would likely have had some impact at the sites with the remaining due to background sources. Just as important is the prediction of source areas that did not contribute fallout at the downwind mixing sites. When totaled across all contributing sources, CLS predicted from $36-58 \%$ of the total fallout concentrations measured at the mixing sites. Improved sampling methods (more samples, evaluation of additional source areas, performing source area and mixing zone sampling after the same snowfall event) are needed to increase our confidence in these CLS predictions and will likely increase the percentage of predicted source contributions accounted for in measured fallout. 


\section{REFERENCES}

1. Henry, R.C. Multivariate Receptor Models. In Receptor Modeling for Air Quality Management, Hopke, P.K., Ed.; Elsevier: Amsterdam, 1991 pp 117-147.

2. Thurston, G.D.; Spengler, J.D. Atmospheric Environment 1985, 19, 9-25.

3. Rahn, K.A.; Lowenthal, D.H. Science 1984, 223, 132-138.

4. Dvonch, J.T., Graney, J.R., Keeler, G.J., Stevens, R.K., Environ. Sci. Technol. 1999, 33, 4522-4527.

5. Abbott, M.L.; Susong, D.D.; Krabbenhoft, D.P. Water, Air, Soil Pollut. 2002, 139, 95114.

6. U.S. EPA Method 1669, Method for sampling ambient water for the determination of metals at EPA ambient criteria levels; U.S. Environmental Protection Agency, Office of Water, Office of Science and Technology, Engineering and Analysis Division (4303); Washington, DC, Jan 1996.

7. Garbarino, J.R.; Taylor, H.E. U.S. Geological Survey Open-File Report 94-358, 49 p.

8. U.S. EPA Method 1631, Revision B, Mercury in water by oxidation, purge, and trap, and cold vapor atomic fluorescence spectrometry; U.S. Environmental Protection Agency, Office of Water, Office of Science and Technology, Engineering and Analysis Division (4303): Washington, DC, Jan 1999.

9. Sagendorf, J. F.; Carter, R.G.; Clawson, K.L. MDIFF Transport and Diffusion Models. NOAA Technical Memorandum OAR ARL-238, Air Resources Laboratory, Silver Spring, MD, 2001, 26 pp. 